\title{
ANTIOXIDANT ENZYME ACTIVITIES, LIPID HYDROPEROXIDE IN HUMAN ERYTHROCYTES MEDIATED BY MONO AND DI-CATION: POTENTIAL ROLE OF GALLIC ACID AND ROSEMARY EXTRACT
}

\author{
(Received:12.11.2009)
}

\author{
By \\ A. H. Al-Mustafa \\ Department of Biological Sciences, Mu'tah University, Karak, Jordan
}

\begin{abstract}
The effect of $\mathrm{Li}^{+1}, \mathrm{Cs}^{+1}, \mathrm{Ni}^{+2}, \mathrm{Mo}^{+2}, \mathrm{Mg}^{+2}$ and $\mathrm{Ba}^{+2}$ ions on human erythrocyte antioxidant enzymes was studied. Three doses of each metal $(10,50$ and $100 \mu \mathrm{M})$ were evaluated by their effect on the activity of catalase (CAT), glutathione peroxidase (GpX), glutathione reductase (GR) and glutathione Stransferase (GST) and lipid peroxide level (lipid peroxidation) indicated by malondialdehyde (MDA) formation. Also, the antioxidant activities of rosemary extract and gallic acid in the presence of these metals were examined. Compared to the control, GpX, CAT and GR activities were significantly increased, while the GST activity was significantly decreased in $\mathrm{Ni}^{+2}$ and $\mathrm{Li}^{+1}$ treated cells, whereas, $\mathrm{Cs}^{+1}$ caused a significant increase in GpX, CAT, and GST and decrease in GR activities. However, $\mathrm{Ba}^{+2}$ showed no significant differences in GpX activity, while CAT and GSTs increased and GR decreased significantly. Also, $\mathrm{Mg}^{+2}$ significantly increased the GpX, GR, CAT and GSTs activities. $\mathrm{Mo}^{+2}$ showed a significant decrease in GR activity at high concentration, while GpX, CAT and GSTs increased significantly. $\mathrm{Li}^{+1}, \mathrm{Cs}^{+1}, \mathrm{Ni}^{+2}, \mathrm{Mo}^{+2}$ and $\mathrm{Ba}^{+2}$ caused an increase in MDA formation, whereas, $\mathrm{Mg}^{+2}$ at 100 $\mu \mathrm{M}$ caused a significant decrease in MDA compared to low concentrations. Gallic acid and rosemary extract inhibited lipid peroxidation (MDA) by 28 to $64 \%$ and 9 to $48 \%$, respectively. The results of this study suggest that reactive oxygen species (ROS) might be involved in the $\mathrm{Li}^{+1}, \mathrm{Cs}^{+1}, \mathrm{Ni}^{+2}, \mathrm{Mo}^{+2}, \mathrm{Mg}^{+2}$ and $\mathrm{Ba}^{+2}$ toxicity and their ability to increase or maintain GpX, CAT, GST and GR activities and MDA formation. Gallic acid and rosemary extract as antioxidant were found to inhibit MDA production under oxidative stress conditions. Furthermore, these results indicate that gallic acid and rosemary are capable of protecting erythrocytes against ROS.
\end{abstract}

Key words: antioxidant enzyme, blood oxidative stress, erythrocyte, heavy metals, malondialdehyde, rosemary.

\section{INTRODUCTION}

Metal pollution is the focus of biological research because of their widespread use. The harmful exposure to heavy metals, either by occupation or environment is of biological and toxicological concerns. These metals lead to toxicity and may also mediate development of pathological condition in exposed individuals (DeRosa and Johnson, 1996).

Transition metals as a redox active elements, appear to play an important role in the etiology of cell damage as a result of exposure to metals and to metals-catalyzed reactive oxygen species (ROS) ( Halliwell and Gutteridge, 1984; Sies, 1993; and Kasprzak, 2002).

Erythrocytes are the main target for the metal toxicities (Battistini et al.,1971), which lead to oxidative damage induced by ROS such as superoxide anion $\left(\mathrm{O}_{2}^{-}\right)$and hydroxy radicals $\left(\mathrm{OH}^{-}\right)$and non-free radical species such as hydrogen peroxide $\left(\mathrm{H}_{2} \mathrm{O}_{2}\right)$ (Fridovich, 1997). ROS will initiate the peroxidation of membrane lipids, leading to the accumulation of lipid peroxide and cellular injury. Lipid peroxidation as one of the indicators of oxidative stress in cells was determined by malondialdehyde (MDA) formation (Clemens and Waller, 1987).

Cells have developed different means to overcome the ROS toxicity which included nonenzymatic antioxidants, provided by food constituents (ascorbic acid, glutathione, tocopherols), enzymes regenerating the reduced forms of antioxidants and ROS-scavenging enzymes such as superoxide dismutase (SOD), catalase (CAT), glutathione peroxides (GPx) and glutathione reductase (GR) (Ribarov et al.,1981; 
Clemens and Waller, 1987; Frankel et al.,1996). ROS-scavenging mechanism includes: the dismutation of $\mathrm{O}_{2}^{-}$to $\mathrm{H}_{2} \mathrm{O}_{2}$ catalysed by SOD, and the conversion of $\mathrm{H}_{2} \mathrm{O}_{2}$ to $\mathrm{H}_{2} \mathrm{O}$ by $\mathrm{GpX}$ or $\mathrm{CAT}$ and glutathione regeneration by GR (Pigeolet et al.,1990; Sies, 1993 and Michiels et al., 1994).

Plants, including herbs and spices are potential sources of natural antioxidants such as tocopherols, flavonoids, tannins and phenolic acids. The greatest level of attention among herbs and spices as sources of antioxidants has been focused on rosemary (Rosmarinus officinalis L), which is widely used in many food applications, especially in Mediterranean dishes (Cuvelier et al.,1996; Frankel et al.,1996; Martinez-Tome et al.,2001; Moreno et al.,2006; Erkan et al.,2008; and Hernández-Hernández et al.,2009).

The effects of mono and dication metals on erythrocytes antioxidant system still poorly understood either in vitro or in vivo. Therefore, the purposes of the present work were to determine the potential changes in antioxidants enzymes activities such as CAT, GpX, GR and GST; lipid peroxidation (MDA) levels, when the erythrocytes are exposed to metals $\left(\mathrm{Li}^{+1}, \mathrm{Cs}^{+1}, \mathrm{Ni}^{+2}, \mathrm{Mo}^{-2}, \mathrm{Mg}^{+2}\right.$ and $\mathrm{Ba}^{+2}$ ) ions in vitro. Also, to investigate the inhibition of MDA formation by antioxidants such as gallic acid as pure compound and rosemary extract as complex plant matrices.

\section{MATERIALS AND METHODS}

\subsection{Chemicals}

Glutathione reductase, t-butylhydroperoxide, reduced glutathione, gallic acid and 1-chloro-2,4dintrobenzene were purchased from Sigma Aldrich Chemical Co. (Germany). Magnesium chloride was obtained from Fluke (Germany). Hydrogen peroxide and cesium chloride were from GCC (England). Barium chloride was purchased from BDH England. NADPH and oxidized glutathione were purchased from Applichem (Germany). Lithium chloride was purchased from Pharmacos ltd (England). Nickel chloride $6 \mathrm{H}_{2} \mathrm{O}$ was purchased from Philip Harris England. Sodium molybdate, was obtained from SDS Fine Chemical Company (India). Hemoglobin Reagent Kit from Techo Diagnostics, USA.

\subsection{Rosemary extract preparation}

Leaves of Rosmarinus officinalis L. were collected from Mutah University campus area (Southern of Jordan) in May 2008 and dried at room temperature $\left(25^{\circ} \mathrm{C}\right)$ for 3 days. Then chopped and extracted with $80 \%$ ethanol for $12 \mathrm{~h}$ at room temperature. The extract was then filtered, evaporated under reduced pressure to obtain a viscous mass of dark green extract. An aliquot of the extract was solubilized in ethanol to a final concentration of $1.0 \mathrm{mg} / \mathrm{mL}$.

\subsection{Preparation of blood sample}

Blood was collected into test tubes containing ethylene diaminetetra acetate (EDTA) from normal human volunteers and not occupationally exposed to heavy metals. EDTA-blood was centrifuged; the clear plasma and puffy coat layers were discarded. The RBC suspension was filtered through cotton wool to remove any leftover leukocytes. RBC were washed with cold $0.15 \mathrm{M}$ sodium chloride solution three times after a 1- to10 dilution. The hemolysates were prepared then by adding $0.9 \mathrm{ml}$ of distilled water to $0.1 \mathrm{ml}$ of diluted RBC, and they were frozen at $-20{ }^{\circ} \mathrm{C}$ for future analysis. Hemoglobin concentration was determined by hemoglobin kit.

\subsection{In Vitro metals treatment}

Phosphate-buffer ( $\mathrm{pH}$ 7.4) was used to dilute the washed erythrocytes $(1: 10)$. Aliquots of the cell suspension were placed in $15 \mathrm{ml}$ screw caped test tubes in the presence of 10,50 and $100 \mu \mathrm{M}$ of cesium chloride $\left(\mathrm{Cs}^{+1}\right)$, lithium chloride $\left(\mathrm{Li}^{+1}\right)$, magnesium chloride $\left(\mathrm{Mg}^{+2}\right)$, barium chloride $\left(\mathrm{Ba}^{+2}\right)$, nickel chloride $\left(\mathrm{Ni}^{+2}\right)$ and sodium molybdate $\left(\mathrm{Mo}^{-2}\right)$. The contents of the tubes were incubated win the shaking in water bath at $37^{\circ} \mathrm{C}$ for 12 h. $0.2 \mathrm{mM}$ EDTA- phosphate buffer was added to treated erythrocytes before biochemical analyses. The control without metals was included each time.

\subsection{Hemoglobin measurement}

The hemoglobin concentration was determined by hemoglobin Reagent Kit from Techo Diagnostics, USA.

\subsection{Antioxidants enzymes assay}

The activities of GST, GR, GpX and CAT were determined spectrophotometrically in red blood cells hemolysates after incubation with metals for $12 \mathrm{~h}$. GSTs activity was measured by the spectrophotometric assay of Habig et al. (1974). GR activity was assayed as described by Gupta et al.(1999). GpX activity with t-butylhydroperoxide was determined according to the method of Lawrence and Burk (1976). CAT activity was measured spectrophotometrically by monitoring the decrease in $A_{240}$ resulting from the elimination of $\mathrm{H}_{2} \mathrm{O}_{2}$ as described by Aebi (1984). The specific activity of GSTs, GR, GpX and CAT was expressed as $\mu \mathrm{mol} / \mathrm{min} / \mathrm{g}$ hemoglobin $(\mathrm{U} / \mathrm{g}$ $\mathrm{Hb}$ ). Blank reactions with lytic cell replaced by distilled water were subtracted from each assay. 


\subsection{Lipid peroxide assay}

The MDA levels were measured by the double heating method (Draper and Hadley, 1990). The erythrocytes were lysed with distilled water and then used for MDA determination. The principle of the method was based on the spectrophotometric measurement of the color developed during the reaction of thiobarbituric acid (TBA) with MDA. The concentration of TBA-MDA complex was calculated (absorbance coefficient $\mathrm{E}=1.56 \times 105 \mathrm{~cm}-1 \mathrm{M}-1$ at $532 \mathrm{~nm}$ ) and expressed as $\mu \mathrm{mol} / \mathrm{g} \mathrm{Hb}$.

\subsection{Gallic acid and rosemary extract: anti-lipid peroxidation}

An erythrocyte suspension (10\%) was incubated with PBS (control) and preincubated with rosemary extracts $(100 \mu \mathrm{g} / \mathrm{mL})$ or gallic acid $(100 \mu \mathrm{g} / \mathrm{mL})$ separately at $37{ }^{\circ} \mathrm{C}$ for $30 \mathrm{~min}$, followed by incubation with and without metals $(100 \mu \mathrm{M})$ in PBS at $\mathrm{pH}$ 7.4. This reaction mixture was shaken gently while being incubated for a 12 $\mathrm{h}$ at $37{ }^{\circ} \mathrm{C}$. One $\mathrm{ml}$ of $1: 1$ ratio of the reaction mixture and a hypotonic buffer $(5 \mathrm{mM}$ phosphate buffer at $\mathrm{pH} 7.4 ; 100 \%$ hemolysis) was removed and used for the MDA analysis.

\subsection{Statistical analysis}

Data are expressed as means \pm SE $(n=5)$ (results obtained from 5 different experiments). Significant differences between the control and heavy metal treated red cells were determined by ANOVA. Differences were considered significant when $\mathrm{P}<0.05$.

\subsection{GST activity}

\section{RESULTS}

The GST activity was increased significantly ( $\mathrm{p}<0.05$ ) when exposed to $10 \mu \mathrm{M}$ of $\mathrm{Cs}^{+1}, \mathrm{Mg}^{+2}$ and $\mathrm{Mo}^{+2}$. Whereas, the $\mathrm{Ni}^{+2}$ caused a significant decrease in GST activity relative to the control. Moreover, at high concentration up to $100 \mu \mathrm{M}$ $\mathrm{Ba}^{+2}$, a significant change in GST activity was detected. Also, $\mathrm{Cs}^{+1}, \mathrm{Li}^{+1}, \mathrm{Ni}^{+2}$ and $\mathrm{Mo}^{-2}$ at 100 $\mu \mathrm{M}$ caused a significant decrease in GST activity (Table 1).

\subsection{GpX activity}

The GpX activity showed a statistical significance changes $(p<0.05)$ when the erythrocytes incubated with $10 \mu \mathrm{M} \mathrm{Cs}{ }^{+1}, \mathrm{Li}^{+1}$, $\mathrm{Ni}^{+2}, \mathrm{Ba}^{+2}, \mathrm{Mg}^{+2}$ and $\mathrm{Mo}^{+2}$ and their activity was increased by $44.3 \%, 28.8 \%, 18 \%, 12.4 \%$, $51.2 \%$, and $32.4 \%$, respectively. Moreover, at high concentration up to $100 \mu \mathrm{M}$ of $\mathrm{Mg}^{+2}$, no significant change in activity was detected. However, GpX displayed no changes in activity toward $\mathrm{Cs}^{+1}, \mathrm{Li}^{+1}, \mathrm{Ni}^{+2}, \mathrm{Ba}^{+2}$ and $\mathrm{Mo}^{-2}$ at $100 \mu \mathrm{M}$ when compared to the effect at low concentrations (Table 1).

\subsection{CAT activity}

In Table 1, CAT activity was increased (35\%) at $50 \mu \mathrm{M} \mathrm{Mo}^{+2}$ and no further increase at $100 \mu \mathrm{M}$ $\mathrm{Mo}^{+2}$, was detected. Also, CAT activity increased significantly $(\mathrm{p}<0.05)$ up to $138 \%$ by increasing the $\mathrm{Mg}^{+2}$ concentration.. The CAT showed 2 fold increments in activity at $100 \mu \mathrm{M} \mathrm{Mg}^{+2}$. Also, $\mathrm{Ba}^{+2}$ caused a significant increase in erythrocytes CAT activity $(\mathrm{p}<0.05)$ and it was concentration dependent when compared to the control (Table 1).

\subsection{GR activity}

An overall no significant changes in GR activity occurred in treated cells at $10 \mu \mathrm{M}$ in comparing to the control. However, it was significantly increased by $314 \%$ and $52 \%$ at 100 $\mu \mathrm{M} \quad \mathrm{Li}^{+1}$ and $\mathrm{Ni}^{+2}$, respectively $(\mathrm{p}<0.05)$. Moreover, the GR activity was significantly inhibited at $100 \mu \mathrm{M} \mathrm{Cs}^{+1}, \mathrm{Ba}^{+2}$ and $\mathrm{Mo}^{+2}$ by $54 \%$, $59 \%$ and $59 \%$ respectively when compared to the control (Table 1).

\subsection{Lipid peroxide (LPO)}

A significant increase in the level of LPO, measured as MDA content, was observed in all treated erythrocytes at all concentrations, being maximum with erythrocytes $+100 \mu \mathrm{M} \mathrm{Ni}{ }^{+2}$ (191\%) followed by $\mathrm{Cs}^{+1}(89 \%), \mathrm{Ba}^{+2}(79 \%), \mathrm{Li}^{+1}$ $(71 \%), \mathrm{Mo}^{-2}(64 \%)$, and $\mathrm{Mg}^{+2}(52 \%)$ after $12 \mathrm{~h}$. Moreover, the MDA level was increased significantly as the metal concentration increased except in case of $\mathrm{Li}^{+1}$ and $\mathrm{Cs}^{+1}$ decreased significantly when compared to normal. Also, $\mathrm{Li}^{+1}$ and $\mathrm{Cs}^{+1}$ increased the MDA level at $10 \mu \mathrm{M}$ more than the other metals. The oxidizing power was $\mathrm{Li}^{+1}>\mathrm{Cs}^{+1}>\mathrm{Mg}^{+2}>\mathrm{Ba}^{+2}, \mathrm{Mo}^{-2}>\mathrm{Ni}^{+1}$ and the MDA was $158,63,44,40,32$ and $23 \%$, respectively (Table 2).

\subsection{Anti-lipid peroxidation of gallic acid and rosemary extract}

The MDA formation induced by the metals after rosemary extract and gallic acid treatment is summarized in (Table 3 ). The rosemary extract and gallic acid decreased MDA levels significantly, in erythrocytes treated with and without metals when compared to the control. On the other hand, gallic acid showed more pronounced antioxidant activity against lipid peroxidation. A decrease in the level of MDA was observed in $\mathrm{Cs}^{+1}, \mathrm{Li}^{+1}, \mathrm{Ni}^{+2}, \mathrm{Mo}^{-2}, \mathrm{Mg}^{+2}$ and $\mathrm{Ba}^{+2}$ treated cells at $100 \mu \mathrm{M}+100 \mu \mathrm{g} / \mathrm{ml}$ gallic acid, being maximum with gallic acid $+\mathrm{Ni}^{+2}(64 \%), \mathrm{Li}$ 
Table (1): Effect of some mono and di-cations on human erythrocytes antioxidant enzyme activities after $12 \mathrm{~h}$ incubation.

\begin{tabular}{|c|c|c|c|c|}
\hline Parameters & & Luman erythrocy & antioxidant en & \\
\hline Metals & $\mathrm{CAT}(\mathrm{U} / \mathrm{g} \mathrm{Hb})$ & $\mathrm{GpX}(\mathrm{U} / \mathrm{g} \mathrm{Hb})$ & GR (U/g Hb) & GST (U/g Hb) \\
\hline Control & $4.18^{\mathrm{a}}$ & $11.05^{\mathrm{a}}$ & $1.24^{\mathrm{a}}$ & $3.92^{\mathrm{a}}$ \\
\hline $\begin{array}{c}\mathrm{Cs}^{+1} \\
10 \mu \mathrm{M} \\
50 \mu \mathrm{M} \\
100 \mu \mathrm{M} \\
\mathrm{SE} \\
\end{array}$ & $\begin{array}{c}7.06^{\mathrm{b}} \\
6.25^{\mathrm{b}} \\
11.35^{\mathrm{c}} \\
1.36 \\
\end{array}$ & $\begin{array}{c}15.94^{\mathrm{b}} \\
21.54^{\mathrm{c}} \\
13.00^{\mathrm{a}} \\
1.86 \\
\end{array}$ & $\begin{array}{c}0.92^{\mathrm{b}} \\
0.70^{\mathrm{bc}} \\
0.57^{\mathrm{c}} \\
0.26 \\
\end{array}$ & $\begin{array}{c}4.82^{\mathrm{b}} \\
4.60^{\mathrm{b}} \\
4.02^{\mathrm{a}} \\
0.11 \\
\end{array}$ \\
\hline $\begin{array}{l}\mathrm{Li}^{+1} \\
10 \mu \mathrm{M} \\
50 \mu \mathrm{M} \\
100 \mu \mathrm{M} \\
\quad \mathrm{SE}\end{array}$ & $\begin{array}{l}5.39^{\mathrm{b}} \\
5.55^{\mathrm{b}} \\
3.92^{\mathrm{a}} \\
0.57\end{array}$ & $\begin{array}{c}14.23^{\mathrm{b}} \\
12.99^{\mathrm{a}} \\
12.32^{\mathrm{a}} \\
1.23\end{array}$ & $\begin{array}{l}1.40^{\mathrm{a}} \\
1.78^{\mathrm{a}} \\
5.13^{\mathrm{b}} \\
0.37\end{array}$ & $\begin{array}{c}4.15^{\mathrm{a}} \\
3.93^{\mathrm{a}} \\
3.65^{\mathrm{b}} \\
0.1\end{array}$ \\
\hline $\begin{array}{c}\mathrm{Ni}^{+2} \\
10 \mu \mathrm{M} \\
50 \mu \mathrm{M} \\
100 \mu \mathrm{M} \\
\quad \mathrm{SE} \\
\end{array}$ & $\begin{array}{l}6.10^{\mathrm{b}} \\
4.91^{\mathrm{a}} \\
4.72^{\mathrm{a}} \\
0.65 \\
\end{array}$ & $\begin{array}{c}13.05^{\mathrm{b}} \\
13.09^{\mathrm{b}} \\
13.25^{\mathrm{b}} \\
0.51 \\
\end{array}$ & $\begin{array}{l}0.70^{\mathrm{a}} \\
1.64^{\mathrm{b}} \\
1.88^{\mathrm{b}} \\
0.37 \\
\end{array}$ & $\begin{array}{c}3.34^{\mathrm{b}} \\
3.44^{\mathrm{b}} \\
3.54^{\mathrm{b}} \\
0.15 \\
\end{array}$ \\
\hline $\begin{array}{c}\mathrm{Ba}^{+2} \\
10 \mu \mathrm{M} \\
50 \mu \mathrm{M} \\
100 \mu \mathrm{M} \\
\quad \mathrm{SE} \\
\end{array}$ & $\begin{array}{l}5.25^{\mathrm{a}} \\
6.67^{\mathrm{b}} \\
6.83^{\mathrm{b}} \\
1.14 \\
\end{array}$ & $\begin{array}{c}13.67^{\mathrm{b}} \\
11.79^{\mathrm{a}} \\
12.02^{\mathrm{a}} \\
1.25 \\
\end{array}$ & $\begin{array}{l}1.55^{\mathrm{a}} \\
1.25^{\mathrm{a}} \\
0.51^{\mathrm{a}} \\
0.26 \\
\end{array}$ & $\begin{array}{c}4.23^{\mathrm{a}} \\
4.67^{\mathrm{b}} \\
4.95^{\mathrm{b}} \\
0.42 \\
\end{array}$ \\
\hline $\begin{array}{c}\mathrm{Mg}^{-2} \\
10 \mu \mathrm{M} \\
50 \mu \mathrm{M} \\
100 \mu \mathrm{M} \mathrm{SE}\end{array}$ & $\begin{array}{l}5.03^{\mathrm{b}} \\
5.73^{\mathrm{b}} \\
9.98^{\mathrm{c}} \\
0.49 \\
\end{array}$ & $\begin{array}{c}16.71^{\mathrm{b}} \\
13.93^{\mathrm{c}} \\
9.95^{\mathrm{d}} \\
0.47 \\
\end{array}$ & $\begin{array}{l}1.37^{\mathrm{a}} \\
1.88^{\mathrm{b}} \\
1.22^{\mathrm{a}} \\
0.36 \\
\end{array}$ & $\begin{array}{c}4.34^{\mathrm{b}} \\
4.32^{\mathrm{b}} \\
4.32^{\mathrm{b}} \\
0.1 \\
\end{array}$ \\
\hline $\begin{array}{c}\mathrm{Mo}^{-2} \\
10 \mu \mathrm{M} \\
50 \mu \mathrm{M} \\
100 \mu \mathrm{M} \\
\mathrm{SE}\end{array}$ & $\begin{array}{l}4.90^{\mathrm{a}} \\
5.64^{\mathrm{b}} \\
5.13^{\mathrm{a}} \\
0.35\end{array}$ & $\begin{array}{c}14.63^{\mathrm{b}} \\
14.48^{\mathrm{b}} \\
14.6^{\mathrm{b}} \\
0.31\end{array}$ & $\begin{array}{l}1.47^{\mathrm{a}} \\
1.56^{\mathrm{a}} \\
0.51^{\mathrm{b}} \\
0.27\end{array}$ & $\begin{array}{l}4.67^{\mathrm{b}} \\
4.34^{\mathrm{b}} \\
3.76^{\mathrm{a}} \\
0.15\end{array}$ \\
\hline
\end{tabular}

Enzyme activities are represented by mean values of five experiments (U/g Hb). a,b,c,d: Different superscripts show significant differences in the same column (P < 0.05). CAT: Catalase; GpX: glutathione peroxidase; GR: glutathione reductase ;GST: glutathione transferases. SEM.: mean standard error 
Table (2): Malondialdehyde concentration after $12 \mathrm{~h}$ incubation of human erythrocytes in solutions of metal salts.

\begin{tabular}{|c|c|c|c|c|c|c|}
\hline \multirow{2}{*}{ Metal } & \multicolumn{3}{|c|}{ Erythrocytes MDA $(\mu \mathrm{M} / \mathrm{g} \mathrm{Hb})$} & & \\
\cline { 2 - 5 } & Without & $10 \mu \mathrm{M}$ & $50 \mu \mathrm{M}$ & $100 \mu \mathrm{M}$ & SE & Sig. \\
\cline { 2 - 5 } $\mathrm{Cs}^{+1}$ & $0.98^{\mathrm{a}}$ & $1.60^{\mathrm{b}}$ & $1.57^{\mathrm{b}}$ & $1.85^{\mathrm{c}}$ & 0.06 & $* * *$ \\
$\mathrm{Li}^{+1}$ & $0.98^{\mathrm{a}}$ & $2.53^{\mathrm{b}}$ & $1.78^{\mathrm{c}}$ & $1.68^{\mathrm{c}}$ & 0.16 & $*$ \\
$\mathrm{Ni}^{+2}$ & $0.98^{\mathrm{a}}$ & $1.21^{\mathrm{b}}$ & $1.88^{\mathrm{c}}$ & $2.85^{\mathrm{d}}$ & 0.08 & $* *$ \\
$\mathrm{Ba}^{+2}$ & $0.98^{\mathrm{a}}$ & $1.37^{\mathrm{b}}$ & $1.48^{\mathrm{b}}$ & $1.75^{\mathrm{c}}$ & 0.04 & $* *$ \\
$\mathrm{Mg}^{+2}$ & $0.98^{\mathrm{a}}$ & $1.42^{\mathrm{b}}$ & $1.92^{\mathrm{c}}$ & $1.49^{\mathrm{b}}$ & 0.13 & $*$ \\
$\mathrm{Mo}^{+2}$ & $0.98^{\mathrm{a}}$ & $1.30^{\mathrm{b}}$ & $1.50^{\mathrm{c}}$ & $1.61^{\mathrm{c}}$ & 0.08 & $* *$ \\
\hline
\end{tabular}

MDA concentrations are represented by mean values of five experiments and expressed as ( $\mu$ mole/ $\mathrm{g} \mathrm{Hb})$.

*, *****ANOVA tests among concentrations (in the same line) at $P<0.05, P<0.01$ and $P<0.001$ significantly different from the control, respectively. ${ }^{\text {a,b,c,d }}$ Different superscripts show significant differences between the concentrations in the same line. SEM: mean standard error.

Table (3): The effect of Rosemary extract and gallic acid on the level of MDA after $12 \mathrm{~h}$ incubation of human erythrocytes with metal salts.

\begin{tabular}{|c|c|c|c|c|c|}
\hline \multirow[t]{2}{*}{ Metal } & \multicolumn{5}{|c|}{ Erythrocytes MDA ( $\mu \mathrm{M} / \mathrm{g} \mathrm{Hb})$} \\
\hline & $\begin{array}{c}\text { Phosphate } \\
\text { buffer }\end{array}$ & Rosemary extract & Gallic acid & $\mathrm{SE}$ & Sig. \\
\hline Without & $0.98^{\mathrm{a}}$ & $1.03^{\mathrm{a}}(+5 \%)^{\&}$ & $0.45^{\mathrm{b}}(-54 \%)$ & 0.02 & $* * *$ \\
\hline $\begin{array}{l}\text { With } \\
\qquad \mathrm{Cs}^{+1}\end{array}$ & $1.85^{\mathrm{a} \#}$ & $1.69^{\mathrm{a}}(-9 \%)$ & $1.08^{\mathrm{b}}(-42 \%)$ & 0.06 & $* *$ \\
\hline $\mathrm{Li}^{+1}$ & $1.68^{\text {a\# }}$ & $1.38^{\mathrm{b}}(-18 \%)$ & $0.62^{c}(-63 \%)$ & 0.05 & $* *$ \\
\hline $\mathrm{Ni}^{+2}$ & $2.85^{\mathrm{a} \#}$ & $1.78^{\mathrm{b}}(-38 \%)$ & $1.04^{\mathrm{c}}(-64 \%)$ & 0.07 & $* *$ \\
\hline $\mathrm{Ba}^{+2}$ & $1.75^{\mathrm{a} \#}$ & $0.91^{b}(-48 \%)$ & $1.26^{\mathrm{c}}(-28 \%)$ & 0.11 & $*$ \\
\hline $\mathrm{Mg}^{-2}$ & $1.49^{\mathrm{a} \#}$ & $1.26^{\mathrm{b}}(-15 \%)$ & $0.64^{\mathrm{c}}(-57 \%)$ & 0.08 & $* *$ \\
\hline $\mathrm{Mo}^{-2}$ & $1.61^{\mathrm{a} \#}$ & $1.01^{\mathrm{b}}(-37 \%)$ & $0.75^{\mathrm{c}}(-53 \%)$ & 0.05 & $* * *$ \\
\hline
\end{tabular}

MDA concentrations are represented by mean values of five experiments and expressed as ( $\mu$ mole/ $\mathrm{g} \mathrm{Hb}$ ). $*, * *, * * *$ ANOVA tests among concentrations (in the same line) at $P<0.05, P<0.01$ and $P<0.001$ significantly different from the control, respectively.

a,b,c, Different superscripts show significant differences between the rosemary, gallic acid and metal in the same line.

\# Sig. difference between the control and metal in the same column. ${ }^{\&}$ (MDA inhibition or activation \%). 
${ }^{+1}(63 \%)$, followed by $\mathrm{Mg}^{+2}(57 \%), \mathrm{Mo}^{+2}$ (53\%), $\mathrm{Cs}^{+1}(42 \%)$ and $\mathrm{Ba}^{+2}(28 \%)$ after $12 \mathrm{~h}$. While a significant decrease in MDA level ranged from 9 to $48 \%$ was observed in the human erythrocytes treated with rosemary extract.

\section{DISCUSSION}

Human erythrocytes represent a useful model to evaluate the effects of ROS. The erythrocyte has a high susceptibility to oxidative stress, because it contains a large amount of polyunsaturated fatty acids. It is also, exposed more to oxygen, which leads to lipid peroxidation. This plays an important role in the toxicity of many xenobiotics (Oostenbrug et al.,1997; Anane and Creppy, 2001). The erythrocyte has a physiological importance as well as antioxidant capacity (Mendiratta et al., 1998 and Siems et al., 2000). It comprises an intracellular antioxidant enzymes such as SOD, CAT, GpX, GR and GSTs. The present study reports the effects of mono- and di-cations (i.e., $\mathrm{Cs}^{+1}, \mathrm{Li}^{+1}, \mathrm{Ni}^{+2}, \mathrm{Ba}^{+2}, \mathrm{Mg}^{+2}, \mathrm{Mo}^{+2}$ ) on the lipid peroxidation, and the antioxidant systems in human erythrocytes in vitro.

Oxidative damage as a result of ROS, leads to the formation of metHb, which will be reduced to ferrohemoglobin through several antioxidants to restore hemoglobin function. The reduction of metHB and GSH is achieved by the action of NADH and NADPH, derived from the glycolysis and oxidative pentose phosphate pathways. GSH in erythrocytes acts in the antioxidant GSH defense system, particularly metHb reductase, GpX, GR,GST and CAT, as well as the small molecules ascorbate and vitamin $\mathrm{E}$ (Siems et al.,2000). In the absence of an efficient antioxidant systems, oxidative stress will cause the release of an active form of iron $\left(\mathrm{Fe}^{+3}\right)$. If the oxidative stress continues, sequential formation of harmful molecules occurs, leading to oxidative damage due to chronic redox imbalances which cause the hemolytic in the erythrocytes, because of membrane damage, via the Fenton -type reaction (Jain et al.,1983; Pardo-Andreu et al., 2005).

The obtained results showed that $\mathrm{Cs}^{+1}, \mathrm{Li}^{+1}$, $\mathrm{Ni}^{+2}, \mathrm{Ba}^{+2}, \mathrm{Mg}^{+2}$ and $\mathrm{Mo}^{+2}$ have a role in the induction of oxidative stress indicated by a significant enhancement of MDA production, in the treated erythrocytes. This increase may be associated with the metal activities as redox molecules. This is in accordance with previous works of Prakash and Rao (1995), Anane and Creppy (2001), Dua and Gill (2001) and AlMustafa (2006).
A previous work shows that ROS formation in the erythrocytes will be formed because of the interaction between hemoglobin and redox metals (Winterbourn, 1983). This oxidative stress gives rise to the $\mathrm{O}_{2}^{-}, \mathrm{H}_{2} \mathrm{O}_{2}$ and peroxy radicals. This will induce membrane lipid peroxidation and hemolysis (Clemens and Waller, 1987). The generation of ROS may be also a result of interaction between metal and erythrocyte membranes. It was found that the interaction of $\mathrm{CuCl}_{2}$ with erythrocyte membrane is accompanied with $\mathrm{O}_{2}^{-}$and $\mathrm{H}_{2} \mathrm{O}_{2}$ generation. Therefore, it initiates peroxidative processes in erythrocytes, and ends with the hemolysis (Stocks and Dormandy, 1971; Ribarov and Bochev, 1984).

The erythrocyte antioxidant enzymes contribute to the maintenance of a relatively low level of the ROS generated through the HaberWeiss reaction and Fenton reaction (Hidalgo et al., 2002; Sanchez et al., 2005). When erythrocytes were treated with $\mathrm{Cs}^{+1}, \mathrm{Li}^{+1}, \mathrm{Ni}^{+2}$, $\mathrm{Ba}^{+2}, \mathrm{Mg}^{+2}$ and $\mathrm{Mo}^{+2}$ in vitro, the activities of GSTs, GR, CAT and GpX were altered (Table 1).

GSTs play an important role in detoxification and metabolism of the lipid hydroperoxides, many xenobiotic and endobiotic compounds. The decrease in the activity of GSTs in human erythrocytes treated with metals was found in the studies of Hunaiti and Soud (2000) and AlMustafa (2006). This might be a result of a decrease of GSH level, because the GST consume the GSH during the peroxide and metals detoxification ( Hunaiti and Soud, 2000). The metals alter the activity of antioxidant system such as GST, CAT, GpX and GR, because of ROS production, through intracellular thiols oxidation (i.e., GSH) and /or via interaction with thiols which are central components of redox-sensitive proteins (Kasprzak, 2002). Also, GSH play a role as intracellular cations chelator through the cysteine residue (Aust et al.,1985), in addition to serving as a substrate for the GpX, GR and GSTs. Its regeneration is also affected by metals, therefore, it affects the GSH dependent enzyme activities (Grose et al.,1987; Ochi et al.,1988; and Mates, 2000).

The GpX activity was increased after treatment with $\mathrm{Cs}^{+1}, \mathrm{Li}^{+1}, \mathrm{Ni}^{+2}, \mathrm{Ba}^{+2}, \mathrm{Mg}^{+2}$ and $\mathrm{Mo}^{+2}$. This is due to $\mathrm{O}_{2}^{-}, \mathrm{H}_{2} \mathrm{O}_{2}$ and lipid peroxide formation. $\mathrm{GpX}$, is responsible for enzymatic defense against $\mathrm{H}_{2} \mathrm{O}_{2}$ and is strictly dependent on the concentration of GSH because it catalyses the reaction between GSH and $\mathrm{H}_{2} \mathrm{O}_{2}$, resulting in the formation of glutathione disulphide (GSSG). Furthermore, GpX activity is linked to the activity 
of GR, which supplies reducing equivalent for GpX function to maintain the cell integrity and its antioxidant system (Paglia and Valentine, 1967).

The present results also showed that CAT activity was significantly increased with gradual increase of $\mathrm{Cs}^{+1}, \mathrm{Ba}^{+2}$ and $\mathrm{Mg}^{+2}$ concentrations $(\mathrm{p}<0.001)$, whereas, dual effects were found on $\mathrm{Li}^{+1}$ and $\mathrm{Ni}^{+2}$ - treated cells. Moreover, CAT inhibition previously, related to the accompanied direct binding of metal ions to $-\mathrm{SH}$ groups on the enzyme molecule, caused the increase in $\mathrm{O}_{2}^{-}, \mathrm{H}_{2} \mathrm{O}_{2}$ due to oxidative stress. It was indicated that rapid inactivation of CAT at high hydrogen peroxide concentration was due to the converting of active enzyme to inactive compounds (Wong and Whitaker, 2002).

GR was significantly inhibited at $100 \mu \mathrm{M} \mathrm{Cs}^{+1}$, $\mathrm{Ba}^{+2}$ and $\mathrm{Mo}^{+2}$. Such inhibition has previously observed in carp tissues treated with $\mathrm{Cu}^{+2}$ (Winston and Di Giulio, 1991) and in sea bass erythrocytes (Roche and Boge, 1993). This may be due to the inhibition of pentose phosphate pathway, which is important for the regeneration of GSH.

Many studies have been performed on the properties of Rosemary (Rosmarinus officinalis L.) in different systems and shown to be a potent scavenger of a variety of ROS and has been widely used as an antioxidant. Phenolic compounds, such as carnosic acid, carnosol, rosmanol, rosmariquinone and rosmaridiphenol have been identified as major constituents that contribute to the antioxidant activity of rosemary (Aruoma et al.,1992; Erkan et al., 2008). Many reports indicated that rosemary extracts can retard lipid oxidation and prolong the shelf life of meat products through the break free radical chain reactions by donation hydrogen atoms. The ROSscavenging and transition metal-chelating activities of Rosemary extract might contribute to the inhibitory effects on lipid peroxidation. Frankel et al. (1996) showed that rosmarinic acid reduces transition metals including iron and copper. In addition, rosmarinic acid can reduce $\mathrm{Mo}(\mathrm{VI})$ to $\mathrm{Mo}(\mathrm{V})$, preventing the product of free radicals caused by the metal (Petersen and Simmonds, 2003).

The data shown in (Table 3) reveal that gallic acid and rosemary extract has a marked capacity for lipid peroxidation inhibition, suggesting that its main action as a peroxidation inhibitor and may be related to its metals binding capacity. This provides an important antioxidative effects by retarding metal-catalysed oxidation (Halliwell and
Gutteridge, 1990). Curcumin, tocopherol and trolox showed ferrous ion chelating activities (Dinis et al.,1994). Also, Kazazic et al. (2006) demonstrated that flavonoids, such as kaempferol, chelated $\mathrm{Cu}^{2+}$ and $\mathrm{Fe}^{2+}$ through the functional carbonyl groups .

In conclusion, these findings demonstrate that in vitro administration of $\mathrm{Cs}^{+1}, \mathrm{Li}^{+1}, \mathrm{Ni}^{+2}, \mathrm{Ba}^{+2}$, $\mathrm{Mg}^{+2}$ and $\mathrm{Mo}^{+2}$ to erythrocyte cells results in the induction of MDA and changes in antioxidant system, supporting that ROS may be involved in the toxic effects of these metals. While gallic acid and Rosemary extracts are capable of protecting erythrocytes against oxidative damage by reducing the MDA probably by acting as a strong antioxidant. Finally it is suggested that the in vivo effects of $\mathrm{Cs}^{+1}, \mathrm{Li}^{+1}, \mathrm{Ni}^{+2}, \mathrm{Ba}^{+2}, \mathrm{Mg}^{+2}$ and $\mathrm{Mo}^{+2}$ should be investigated further.

\section{Acknowledgement}

This study was supported by Mutah University-Research Deanship grant number 120/14/430, 2007.

\section{REFERENCES}

Aebi H. E. (1984). Catalase in vitro. Methods Enzymol. 105: 121-126.

Al-Mustafa A.H. (2006). In vitro study involving the comparative effect of heavy metal ions on antioxidant enzyme activity and lipid peroxide level in human erythrocytes. Pak. J. Biol. Sci. 9: 2586-2592.

Anane R. and Creppy E.E. (2001). Lipid peroxidation as pathway of aluminium cytotoxicity in human skin fibroblast cultures: prevention by superoxide dismutase + catalase and vitamins $\mathrm{E}$ and $\mathrm{C}$. Hum. Exp. Toxicol. 20: 477-481.

Aruoma O.I., Halliwell B., Aeschbach R. and Löligers J. (1992). Antioxidant and prooxidant properties of active rosemary constituents: Carnosol and carnosic acid. Xenobiotica. 22: 257-268.

Aust S.D., Morehouse L.A. and Thomas C.E. (1985). Role of metals in oxygen radical reactions. J. Free Radic. Biol. Med. 1: 3-25.

Battistini V., Marrow J.J., Gensburg D., Thompson G. Moore M,R. and Goldberg A. (1971). Erythrocyte delta-amino levulinic acid dehydrase activity in anaemia. Br. J. Haematol. 20: 177-184.

Clemens M.R. and Waller H.D. (1987). Lipid peroxidation in erythrocytes. Chem. Phys. Lipids. 45: 251-68.

Cuvelier M.E., Richard H. and Berset C. (1996). 
Antioxidative activity and phenolic composition of pilot-plant and commercial extracts of Sage and Rosemary. J. Amer Oil Chemists Soc. 73: 645-652.

DeRosa C.T. and Johnson B.L. (1996). Strategic elements of ATSDR's Great Lakes Human Health Effects Research Program. Toxicol. Ind. Health. 12: 315-25.

Dinis T.C.P., Madeira V.M.C. and Almeida L.M. (1994). Action of phenolic derivates (acetaminophen, salicylate, and 5- aminosalicylate) as inhibitors of membranelipidperoxidation and as peroxyl radical scavengers. Arch. Biochem. Biophys. 315: 161-169.

Draper H.H. and Hadley M. (1990). Malondialdehyde determination as index of lipid peroxidation. Methods Enzymol. 186: 421-431.

Dua R. and Gill K.D. (2001). Aluminum phosphide exposure: implications on rat brain lipid peroxidation and antioxidant defence system. Pharmacol. Toxicol. 89: 315-319.

Erkan N., Ayranci G. and Ayranci E. (2008). Antioxidant activities of rosemary (Rosmarinus officinalis L.) extract, blackseed (Nigella sativa L.) essential oil, carnosic acid, rosmarinic acid and sesamol. Food Chem. 110: 76-82

Frankel E.N., Huang S.W., Aeschbach R. and Prior E. (1996). Antioxidant activity of a Rosemary extract and its constituents, carnosic acid, carnosol, and rosmarinic acid, in bulk oil and oil-in-water emulsion. J. Agric. Food Chem. 44: 131-135.

Fridovich I. (1997). Superoxide anion radical $\left(\mathrm{O}_{2}^{-}\right)$, superoxide dismutases, and related matters. J. Biol. Chem. 272: 18515-7.

Grose E.C., Richards. J.H., Jaskot R.H., Menache M.G., Graham J.A. and Dauterman W.C. (1987). Glutathione peroxidase and glutathione transferase activity in rat lung and liver following cadmium inhalation. Toxicol. 44: 171-9.

Gupta A., Nigam D., Shukla G,S. and Agarwal A.K. (1999). Profile of reactive oxygen species generation and antioxidative mechanisms in the maturing rat kidney. $\mathbf{J}$ Appl Toxicol. 19: 55-9.

Habig W.H., Pabst M.J. and Jakoby W.B. (1974). Glutathione S-transferases. The first enzymatic step in mercapturic acid formation. Biol. Chem. 249: 7130-9.
Halliwell B. and Gutteridge J.M. (1984). Oxygen toxicity, oxygen radicals, transition metals and disease. Biochem. J. 219: 1-14.

Halliwell B. and Gutteridge J.M.C. (1990). Role of free radicals and catalytic metal ions in human disease: An overview. Methods Enzymol.186: 1-85.

Hernández-Hernández E., Ponce-Alquicira E., Jaramillo-Flores M.E. and Guerrero Legarreta I. (2009). Antioxidant effect rosemary (Rosmarinus officinalis L.) and oregano (Origanum vulgare L.) extracts on TBARS and colour of model raw pork batters. Meat Science. 81: 410-417.

Hidalgo M.C., Exposito A., Palma J.M. and Higuera M. (2002). Oxidative stress generated by dietary Zn-deficiency: studies in rainbow trout (Oncorhynchus mykiss). Int. J. Biochem. Cell. Biol. 34: 183-193.

Hunaiti A.A. and Soud M. (2000). Effect of lead concentration on the level of glutathione, glutathione $\mathrm{S}$-transferase, reductase and peroxidase in human blood. Sci Total Environ. 248: 45-50.

Jain S.K., Mohandas N., Clark M.R. and Shobel S.B. (1983). The effect of malonyldialdehyde, a product of lipid peroxidation, on the deformability, dehydration and 51Cr-survival of erythrocytes. Br. J. Haematol. 53: 247-252.

Kasprzak K.S. (2002). Oxidative DNA and protein damage in metal-induced toxicity and carcinogenesis. Free Radic. Biol. Med. 32: 958-967.

Kazazic S.P., Butkovica V., Srzic D. and Klasinc L. (2006). Gas-phase ligation of $\mathrm{Fe}^{+}$and $\mathrm{Cu}^{+}$ions with some flavonoids. J. Agric. Food Chem. 54: 8391-8396.

Lawrence R.A. and Burk R.F. (1976). Glutathione peroxidase activity in selenium-deficient rat liver. Biochem. Biophys. Res. Commun. 71: 952-8.

Martinez-Tome M., Jimenez A.M., Ruggieri S., Frega N., Strabbioli R. and Murcia M.A. (2001). Antioxidant properties of Mediterranean spices compared with common food additives. J. Food Protect. 64: 1412-1419

Mates J.M. (2000). Effects of antioxidant enzymes in the molecular control of reactive oxygen species toxicology. Toxicol.153: 83-104.

Mendiratta S., Qu Z.C. and May J.M. (1998). Erythrocyte ascorbate recycling: antioxidant effects in blood. Free Radic. Biol. Med. 24: 789-97. 
Michiels C., Raes M., Toussaint O. and Remacle J. (1994). Importance of Se-glutathione peroxidase, catalase, and $\mathrm{Cu} / \mathrm{Zn}-\mathrm{SOD}$ for cell survival against oxidative stress. Free Radic. Biol. Med. 17: 235-48.

Moreno S., Scheyer T., Romano C.S. and Vojnov A.A. (2006). Antioxidant and antimicrobial activities of rosemary extracts linked to their polyphenol composition. Free Radic. Res. 40: 223-231.

Ochi T., Otsuka F., Takahashi K. and Ohsawa M. (1988). Glutathione and metallothioneins as cellular defense against cadmium toxicity in cultured Chinese hamster cells. Chem. Biol. Interact. 65: 1-14.

Oostenbrug G., Mensink R., Hardeman M., De Vries T., Brouns F. and Hornstra G. (1997). Exercise performance, red blood cell deformability, and lipid peroxidation: effects of fish oil and vitamin E. J. Appl. Physiol. 83: 746-752.

Paglia D.E. and Valentine W.N. (1967). Studies on the quantitative and qualitative characterization of erythrocyte glutathione peroxidase. J. Lab. Clin. Med. 70: 158-69.

Pardo-Andreu G., Delgado R., Velho J., Inada N.M., Curti C. and Vercesi A.E. (2005). Mangifera indica L. extract (Vimang) inhibits $\mathrm{Fe}^{2+}$-citrate induced lipoperoxidation in isolated rat liver mitochondria. Pharmacol. Res. 51: 427435.

Petersen M. and Simmonds M.S.J. (2003). Rosmarinic acid. Phytochem. 62 : 121-125.

Pigeolet E., Corbisier P. Houbion A., Lambert D., Michiels C. and Raes M., (1990). Glutathione peroxidase, superoxide dismutase, and catalase inactivation by peroxides and oxygen derived free radicals. Mech. Ageing Dev. 51: 283-97.

Prakash N.T. and Rao K.S. (1995). Modulations in antioxidant enzymes in different tissues of marine bivalve Perna viridis during heavy metal exposure. Mol. Cell Biochem. 146: 107-113.

Ribarov S.R. and Bochev P.G. (1984). The interaction of copper chloride with erythrocyte membrane as a source of activated oxygen species. A chemiluminescent study. Gen. Physiol. Biophys. 3: 431-5.

Ribarov S.R., Benov L.C. and Benchev I.C. (1981). The effect of lead on hemoglobin catalyzed lipid peroxidation. Biochim. Biophys. Acta. 664: 453-459.

Roche H. and Boge G. (1993). Effect of $\mathrm{Cu}, \mathrm{Zn}$ and $\mathrm{Cr}$ salts on antioxidant activities of Marine fish Dicentrarchus labrax in vitro of red blood cells. Toxic. in vitro. 7: 623-629.

Sanchez W., Palluel O., Meunier L., Coquery M., Porcher J.M. and Ait-Aissa S. (2005). Copper-induced oxidative stress in threespined stickleback: relationship with hepatic metal levels. Environ. Toxicol. Pharmacol. 19 : 177-183.

Siems W.G., Sommerburg O. and Grune T. (2000). Erythrocyte free radical and energy metabolism. Clin. Nephrol. 53: S9-17.

Sies H. (1993). Strategies of antioxidant defense. Eur. Biochem. 215: 213-9.

Stocks J. and Dormandy T.L. (1971). The autoxidation of human red cell Lipids induced by hydrogen peroxide. Br. J. Haematol. 20: 95-111.

Winston G.W. and Di Giulio R.T. (1991). Prooxidant and antioxidant mechanisms in aquatic organisms. Aquatic Toxicol. 19: 137-161

Winterbourn C.C. (1983). Haemoglobin oxidation and free radical production in the red cell. Biomed. Biochim. Acta. 42,134-138.

Wong D.W.S. and Whitaker J.R. (2002). Catalase. Handbook of Food Enzymology. New York, USA. 389. PP. 
نشاط إنزيمات مضادة الأكسدة والدهن المؤكسد في كريات الدم الحمراء للإنسان

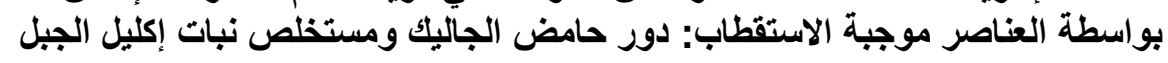

$$
\text { قسم العلوم البيولوجية - جامعة مؤنه - الكركي الكرك - الأردن }
$$

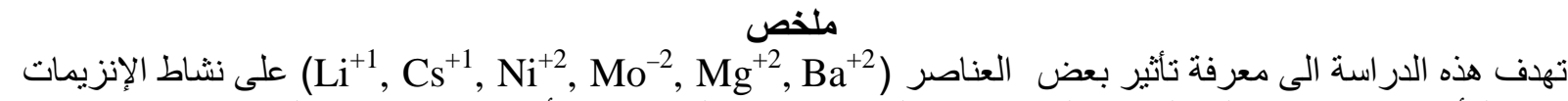

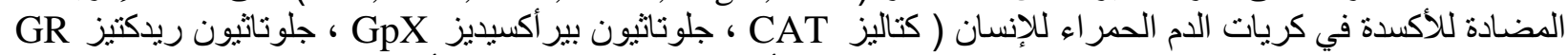

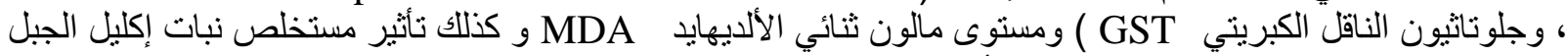

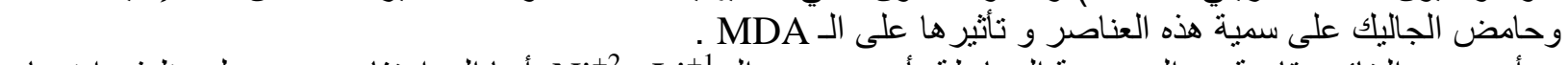

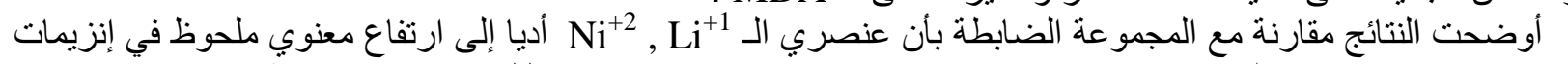

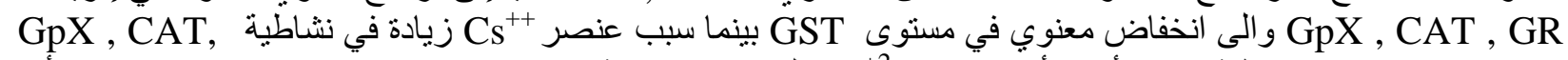
و وانخفاض في نشاطية GST أبضا أدى عنصر Ga عنصر

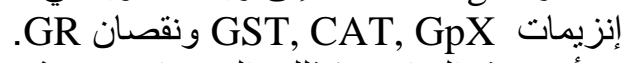

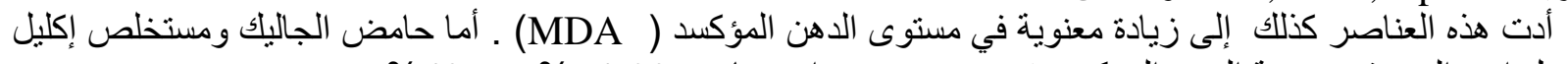

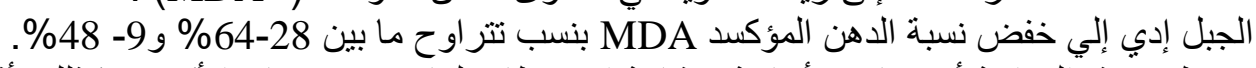

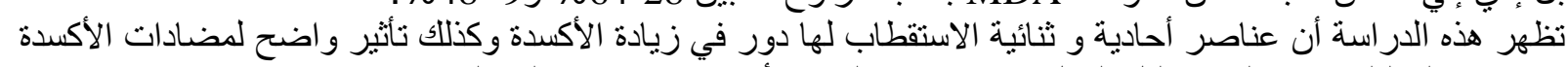

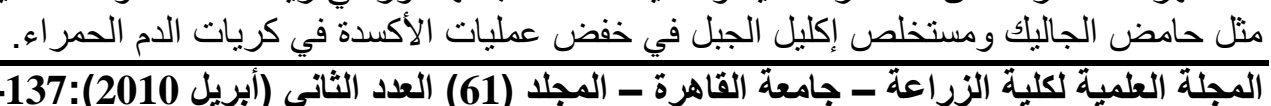

